\title{
An Son Ceramics in the Neolithic Landscape of Mainland Southeast Asia
}

\author{
Carmen Sarjeant
}

\begin{abstract}
Most comparative studies of pottery and other material culture in Mainland Southeast Asia (MSEA) have emphasised well-researched sites in Thailand, with little attention to the archaeological record from southern Vietnam. Recent excavations at An Son provide new opportunities to redress this disparity through comparative research between Neolithic sites in southern Vietnam and those in other parts of MSEA. This research employed systematic methods for data collection and statistical analysis in order to compare the ceramic assemblages and additional material culture at An Son, in the Mekong delta region of southern Vietnam, with 14 other sites in MSEA. The aim of this study was to place An Son and southern Vietnam within the context of Neolithic developments in MSEA at around the second millennium $B C$ by determining regional relationships in the geographic distribution of material cultural traits and identifying regional patterns of connectivity and possible routes of migration that led to the appearance of the Neolithic community at An Son. The analysis suggests that sites in northeast and central Thailand have ancestral links with An Son, with the implication that Neolithic populations perhaps settled An Son via major tributaries of the Mekong River. Additionally, there are strong parallels between the material culture at sites in southeastern Cambodia and southern Vietnam, which suggests continuing contact during the Neolithic.
\end{abstract}

\section{Introduction}

This paper builds on previous research on the relationships between Neolithic sites in Mainland Southeast Asia (MSEA) based on ceramic comparisons (e.g. Rispoli 2007; Wiriyaromp 2007, 2011). It draws upon specific comparisons with the site of An Son, focusing on the 2009 excavation material, in order to place southern Vietnam in the wider context of Neolithic developments in Southeast Asia, ca. 3500 to 2000 BP. A correspondence analysis (CA) is utilised to compare a broad range of sites in MSEA chosen for their Neolithic occupational evidence and accessible excavation reports.

The Neolithic of MSEA has been most intensively researched in central and northeast Thailand (e.g. Higham and Bannanurag 1990; Ciarla 1992; Rispoli 1992; Higham and Thosarat 1998a; Nguyen 2006; Higham and Kijngam 2009; Oxenham et al. 2011). Over the past two decades, research, surveys and excavations have increased in southern Vietnam along the Vam Co Dong and Vam Co Tay Rivers, adjacent to the Dong Nai and Sai Gon River valleys. Many date to the Bronze and Iron ages (3000-1500 BP), but the Vam Co Dong has a concentration of tested 
Neolithic sites dating to the late third and second millennia BC, including An Son in Long An Province, nearby Loc Giang, and Dinh Ong further upstream in Tay Ninh Province (Figure 9.1; Nishimura 2002; Nishimura and Nguyen 2002).

An Son is so far the most comprehensively excavated site in southern Vietnam with a Neolithic sequence. An Australian Research Council Discovery Grant awarded to Peter Bellwood, Marc Oxenham and Janelle Stevenson, entitled 'The Creation of Southeast Asian Peoples and Cultures, 3500 BC to AD 500' (DP0666607), funded an excavation at An Son in 2009 in collaboration with the Institute of Archaeology, Hanoi and Nguyen Kim Dung and the Centre for Archaeological Studies, Southern Institute of Social Sciences, Ho Chi Minh City and Bui Chi Hoang (Bellwood et al. 2011). This excavation was intended to address the origins of rice agriculture in southern Vietnam and Southeast Asia in general, and to obtain information on the inhabitants from their interment practices and human remains. Within the context of this new research, previous overviews of cultural sequences for Southeast Asia (e.g. Higham 1996: 4; fig. 1.2) could be reworked to include southern Vietnam.

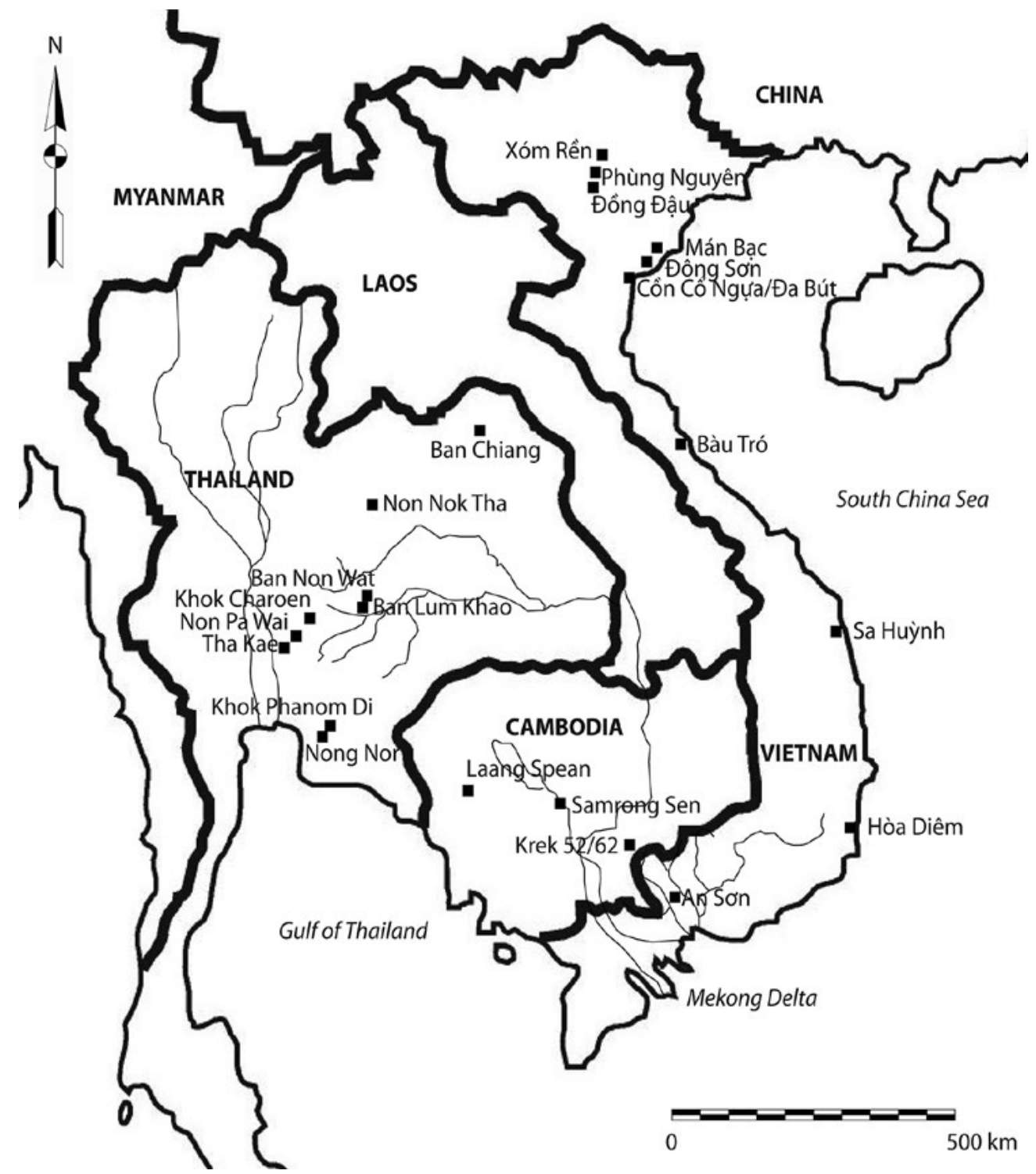

Figure 9.1 Map of An Son and other sites analysed in this contribution.

Source: C. Sarjeant. 
The An Son mound is located in An Ninh Tay Commune, Duc Hoa District at coordinates $10^{\circ} 59^{\prime} 19^{\prime \prime} \mathrm{N} / 106^{\circ} 17^{\prime} 41^{\prime \prime} \mathrm{E}$, close to the northern border of Long An Province where the Vam Co Dong River approaches the Cambodian border (Figure 9.1; Bellwood et al. 2011). It is situated on a slightly raised natural levee overlooking extensive rice fields about 300 m east of the Vam Co Dong and ca. $85 \mathrm{~km}$ from the coast (Nishimura and Nguyen 2002: 101). An Son was initially reported by Louis Malleret and Paul Levy (Malleret 1963: 94-95). The first excavations at An Son were initiated in 1978 on the top of the mound. Little information exists with regards to this excavation, except that the excavators uncovered $c a .4 \mathrm{~m}$ of prehistoric deposits and recovered a substantial collection of cultural remains that are now housed in Long An Provincial Museum.

Further investigations through the mound in 1997 identified three major depositional events. The upper, Unit 1 consisted of disturbed sediments associated with the construction of the modern pagoda atop the archaeological site. Preceding this was Unit 2, which contained a complex sequence of hard-compacted 'earthen' surfaces alternating with soft humic deposits containing high concentrations of pottery and bone and hearth features (Nishimura and Nguyen 2002). Nishimura and Nguyen (2002) interpreted the stratigraphy as representing a series of sequential floor surfaces that had built up through time. Unit 3, the basal mound deposits below Unit 2, consisted of greyish sandy soil truncated by postholes and rich in potsherds. Although the site is located on a river levee of silt, there was little evidence of fluvial sediments in Unit 3. They concluded that Unit 3 had been deliberately brought to the site as a foundation deposit.

In 2004 and 2007, excavations focused on areas eastern edge of the main mound where burials were located. The investigators uncovered 25 extended inhumations. In 2009, excavations by a joint Australian/Vietnamese team positioned their trenches adjacent to the 2004 trenches, with the intention of uncovering more extended burials. A small test square was also opened at the western side of the mound. The excavations produced a further six individuals (Bellwood et al. 2011).

The 2009 excavations at An Son also revealed evidence for a mixed economy, including domestic pig and dog, the Oryza japonica subspecies of rice (as husks in pottery), fish and shellfish from brackish estuarine rivers, and hunted animals. Some of the earliest layers contained domestic dog, but it is uncertain whether the earliest pig remains were domesticated or wild (Piper et al. 2014). Rice chaff was not identified in pottery tempers from the earliest layers of An Son, but appeared shortly after. Other material culture at An Son includes ground and polished stone tools, shell beads, bone fishhooks and worked bone/ivory, ceramic roundels or counters, and baked clay pellets (Bellwood et al. 2011).

The lack of an established chronology for southern Vietnam, largely resulting from insecure radiocarbon dates and lack of stratigraphic understanding, led Nishimura (2002: 50-51) to formulate four periods for the Neolithic occupation of southern Vietnam based on ceramic form and decoration. Period I represented the lowest layers at An Son and Da Kai, beginning around $4000 \mathrm{BP}$. This period possessed a minimal variety in ceramic forms with cord-marking, red paint, and incised wavy motifs. Period II was estimated to date to 4000-3500 BP and exhibited the first appearance of fibre or rice chaff tempered ceramics and a development of earlier incised motifs on ceramics. Period III dated to 3500-3000 BP and had ceramics with zigzag and impressed decorations. Period IV was estimated to date to $3000 \mathrm{BP}$ and had a greater variety of ceramic forms and of impressed decorations. Temporal distinctions are reported for some ceramic features (Bellwood et al. 2011); however, full resolution of the Neolithic sequence in southern Vietnam will require further excavation and an increased understanding of the relationships between sites. 


\section{Neolithic occupation in MSEA}

In keeping with recent research in Vietnam (Oxenham and Tayles 2006; Matsumura and Oxenham 2011), the Neolithic in MSEA is here tentatively applied to 'food-producing communities that lacked evidence for metal'. On that basis, the MSEA Neolithic is thought to have commenced in the late third to early second millennium BC. There are two models for the development of Neolithic occupation in the region (Bellwood and Oxenham 2008; Higham 2011a: 1): the first is an expansionist model whereby farmers from the north moved into areas occupied by indigenous hunter-gatherers; the second prioritises the ability of indigenous groups to adopt cultivated subsistence and technological traits as Neolithic farmers entered the region.

Neolithic sites in MSEA are predominantly distributed either along or near present and former coastlines and rivers, in environments that provided the natural flooding and rainfall required for rice cultivation. Rivers and their tributaries were likely to have been of great importance to the movement of people and ideas in the past. The Neolithic occupation of Vietnam exhibits evidence of contact with China and other regions of MSEA, leading to suggestions that agricultural practices travelled from the north via rivers and/or along the coast (Fuller et al. 2010; Higham et al. 2011). The Neolithic sites exhibit the oldest evidence of cultivation in MSEA, including rice and other crops, supplemented by a hunter-gatherer-fisher economy. Domestic pigs and dogs and shared aspects of ceramic traditions, ground and polished stone assemblages, and bone and shell technologies were evident in sedentary village habitation sites. Recent radiocarbon chronologies suggest that some sites were occupied for more than 1,000 years, whilst others appear to have remained in existence for just a few hundred. An Son has been identified as a Neolithic site due to its late third to second millennium BC where many generations of sedentary inhabitants were occupied in rice cultivation and animal husbandry, and utilised ceramic, stone, shell and bone technologies (Bellwood et al. 2011; Piper et al. 2014).

For the purposes of comparing An Son with other MSEA Neolithic sites, only those with evidence from premetal contexts, both early and late Neolithic, are included, even though only some of these have secure radiocarbon-dated chronologies. Examples with clear and established Neolithic sequences include Ban Non Wat and Man Bac (Higham and Higham 2009a; Oxenham et al. 2011). Tha Kae exhibited Neolithic evidence in the lowest occupational layer 5, while Khok Charoen has one secure date from a burial of $2853 \mathrm{BP}$ and the site is associated with Neolithic material culture (Ciarla 1992; Bulbeck 2011; Ciarla n.d.). Charles Higham suggests Khok Phanom Di and Nong Nor (Phase 1) are hunter-gatherer-fisher sites since there is no secure evidence that the occupants ever cultivated rice. There were some rice remains at Khok Phanom Di but they appear to reflect trade with Neolithic rice cultivators located inland, whereas Nong Nor proceeded directly from a hunter-gatherer site during Phase 1 to a Bronze Age site in Phase 2 (Charles Higham, pers. comm.). Nevertheless, Khok Phanom Di and Nong Nor (Phase 1) are included in the comparison due to similar dates with An Son, so as to represent the coastal region of central Thailand at the time.

The additional sites of Samrong Sen, Laang Spean, early Ban Lum Khao (its early Layer 3 and Mortuary Phase 1, which are considered Neolithic), Ban Chiang (Initial to Early Period I-II), Non Nok Tha (Early Period), Krek, Bau Tro and Xom Ren are also included, even though the contextual information and chronologies for these sites are not particularly secure. In attempting to cover a wide geographic area (Figure 9.1) for a period of time spanning some 1,000 years, a certain allowance for archaeological estimation is unavoidable. The sites compared with An Son are summarised in Table 9.1. 
Table 9.1 Sites in Mainland Southeast Asia with Neolithic sequences included in the comparative study with An Son with dates of occupation and cited publications for the archaeological research.

\begin{tabular}{|c|c|c|c|}
\hline & Location & Date & References \\
\hline $\begin{array}{l}\text { Ban Chiang (Initial Period } \\
\text { to Early Period I-II) }\end{array}$ & $\begin{array}{l}\text { Northeast } \\
\text { Thailand }\end{array}$ & $\begin{array}{l}\text { ca. } 4000 \text { BP (Gorman and } \\
\text { Charoenwongsa 1976) }\end{array}$ & $\begin{array}{l}\text { Gorman and Charoenwongsa 1976; } \\
\text { Bayard 1977; McGovern et al. 1985; } \\
\text { see also Bubpha } 2003\end{array}$ \\
\hline $\begin{array}{l}\text { Ban Lum Khao (Neolithic } \\
\text { Layer } 3 \text { and Mortuary } \\
\text { Phase 1) }\end{array}$ & $\begin{array}{l}\text { Northeast } \\
\text { Thailand }\end{array}$ & $\begin{array}{l}\text { Neolithic occupation: ca. 3450-3000 } \\
\text { BP (T.F.G. Higham in Higham and } \\
\text { Thosarat 2004b: 5) }\end{array}$ & $\begin{array}{l}\text { Chang 2004; Higham and Thosarat } \\
\text { 2004a, 2004b }\end{array}$ \\
\hline $\begin{array}{l}\text { Ban Non Wat (Neolithic } \\
\text { Phases } 1 \text { and 2) }\end{array}$ & $\begin{array}{l}\text { Northeast } \\
\text { Thailand }\end{array}$ & $\begin{array}{l}\text { Neolithic occupation: ca. 3750-3500 } \\
\text { cal. BP Neolithic Phase } 1 \text { burials: } \\
\text { ca. } 3450-3350 \text { cal. BP Neolithic } \\
\text { phase } 2 \text { burials: ca. 3350-3150 cal. } \\
\text { BP (Higham and Higham 2009a, } \\
\text { 2009b) }\end{array}$ & $\begin{array}{l}\text { Wiriyaromp 2007; Higham 2009a, 2009b, } \\
\text { 2009c; Higham and Kijngam 2011; } \\
\text { Higham and Wiriyaromp 2011a, 2011b }\end{array}$ \\
\hline Ваu Тro & $\begin{array}{l}\text { Central } \\
\text { Vietnam }\end{array}$ & са. 4000-3500 BP (Pham 1997) & Patte 1924; Pham 1997 \\
\hline Khok Charoen & $\begin{array}{l}\text { Central } \\
\text { Thailand }\end{array}$ & $\begin{array}{l}2980 \pm 450 \text { BP, } 3180 \pm 300 / 3080 \pm 300 \\
\text { BP (pottery, thermoluminescence) } \\
\text { (Watson 1979), 2853 } \pm 33 \text { BP (burial) } \\
\text { (Bulbeck 2011) }\end{array}$ & Watson 1979; Ho 1984; Higham 2011b \\
\hline Khok Phanom Di & $\begin{array}{l}\text { Coastal central } \\
\text { Thailand }\end{array}$ & $\begin{array}{l}\text { 4000-3500 BP (Higham and } \\
\text { Bannanurag 1990) }\end{array}$ & $\begin{array}{l}\text { Higham and Bannanurag 1990; Higham } \\
\text { and Thosarat 2004c; Vincent } 2004\end{array}$ \\
\hline Krek & Cambodia & $\begin{array}{l}\text { Neolithic material culture } \\
\text { (Dega 1999) }\end{array}$ & Albrecht et al. 2000; Dega 2002 \\
\hline Laang Spean & Cambodia & $\begin{array}{l}\text { Possible Neolithic deposits: ca. } \\
4050 \text { BP (Mourer and Mourer 1970) }\end{array}$ & Mourer and Mourer 1970 \\
\hline Man Bac & $\begin{array}{l}\text { Northern } \\
\text { Vietnam }\end{array}$ & $\begin{array}{l}4000-3500 \text { cal. BP (0xenham et } \\
\text { al. 2008) }\end{array}$ & Nguyen 2006; 0xenham et al. 2011 \\
\hline $\begin{array}{l}\text { Non Nok Tha (Early } \\
\text { Period) }\end{array}$ & $\begin{array}{l}\text { Northeast } \\
\text { Thailand }\end{array}$ & $\begin{array}{l}\text { ca. } 4000 \text { BP (Gorman and } \\
\text { charoenwongsa 1976) }\end{array}$ & $\begin{array}{l}\text { Gorman and Charoenwongsa 1976; } \\
\text { Bayard 1977; Rispoli 1997; Bayard } \\
\text { and Solheim } 2009\end{array}$ \\
\hline Nong Nor (Phase 1) & $\begin{array}{l}\text { Coastal central } \\
\text { Thailand }\end{array}$ & $\begin{array}{l}\text { 4500-4100 cal. BP (Higham and } \\
\text { Hogg 1998) }\end{array}$ & $\begin{array}{l}\text { Higham and Thosarat 1998a, 1998b; } \\
\text { O'Reilly } 1998\end{array}$ \\
\hline Samrong Sen & Cambodia & $\begin{array}{l}3230 \pm 120 \text { BP (Carbonnel and } \\
\text { Delebrias 1968) }\end{array}$ & Mourer 1977; Vanna 2002; Heng 2007 \\
\hline Tha Kae (Layer 3) & $\begin{array}{l}\text { Central } \\
\text { Thailand }\end{array}$ & $\begin{array}{l}\text { Neolithic occupation: end of } \\
\text { the third millennium BC to the } \\
\text { beginning of the second millennium } \\
\text { BC, based on ceramic typologies } \\
\text { (Rispoli 1992, 1997; Ciarla n.d.) }\end{array}$ & Ciarla n.d., 1992; Rispoli 1992, 1997 \\
\hline Xom Ren & $\begin{array}{l}\text { Northern } \\
\text { Vietnam }\end{array}$ & $\begin{array}{l}\text { Phung Nguyen phase/early Bronze } \\
\text { Age (Nguyen 2006) }\end{array}$ & Nguyen 2006; Hán 2009 \\
\hline
\end{tabular}

Source: C. Sarjeant.

\section{Methodology for the correspondence analysis}

Comparison of ceramic assemblages has traditionally relied on classifications using the typevariety system coupled with pottery seriation, stratigraphic analysis and, until chronometric dating techniques became widely available, culture-historical approaches (Dunnell 1986). More recent research often extends beyond classificatory approaches, including rigorous and systematic methods of analysis that study 'phenotypic change as a result of variation and selective 
retention' in order to overcome the untestable nature of the inferences that might otherwise result (Neff 1993: 39). Such systematic and intensive comparative methods, employing many cases and many variables, additionally facilitate an understanding of variation over time and space (Caramani 2009: 15; Smith and Peregrine 2012).

There are many factors that affect comparative studies: sample size, sample selection, contextualisation, spatial and temporal scale, synchronic versus diachronic perspectives, whether the data are primary or secondary, whether the data are archaeological or historical, how the data are interpreted, and stage in research trajectory (Smith and Peregrine 2012). Within this comparative study, the sample size and selection are impacted upon by the nature of the excavation and the recording, analysis, interpretation and publication of the material, especially as so many different researchers across such a wide region are included. This study is presented as a preliminary, systematic and intensive comparison that can be expanded upon as additional information for Southeast Asian contexts becomes available.

Correspondence Analysis (CA) is an exploratory analytical technique that is essentially a principal component analysis of tables of categorical data, and the results are illustrated in a graphical plot of the relationship between the rows and columns of a table (Baxter 2003: 137). The CA undertaken here aims for a systematic comparison of the ceramics and other material culture between sites in southern Vietnam, and MSEA in general, improving on the broad descriptive approaches and illustrative data presentations on which past comparisons have relied. The data employed here result from personal observations of some collections but other collections are represented only by their published documentation. Further, to relate the chronology of the analysed sites to the sequence at An Son, the material culture at An Son was divided into a burial phase and early, middle and late phases of occupation.

In the present study, each material-culture trait was treated separately as a single variable. This is to account for and manage the high variability of material culture when a wide geographic area is examined. Further, each variable was scored as present (1) or absent (0), because reliable quantitative data are not available for most of the sites. Absence was assigned when no information for that variable was available; this may not always mean that the variable concerned was not present, but that there is no evidence for its presence. The CA was conducted with GenStat software (VSN International 2011).

The identified variables for the CA included the major ceramic vessel forms, modes of decoration and surface treatment, location of decoration on ceramic vessels, ceramic temper when possible, and the presence (or absence) of animal bones, specific stone tools, other stone and bone/ivory tools and ornaments, and ceramic/clay items like roundels and pellets at An Son and the other 14 assessed sites. A total of 131 cultural variables were included in the CA, of which 73 were ceramic vessel variables and the remaining 58 were other material-culture variables (Table 9.2).

The CA resulted in values for a number of dimensions, of which two were then plotted. The correspondence scores for the sites and variables were plotted to identify the sites that are most similar or different in terms of material culture, and also the material culture variables that resulted in these similarities and differences. Two plots are presented for each analysis, one of the material-culture variables and one of the sites. The scale on these plots reflects the variability of the total analysed sample (Figure 9.2). 

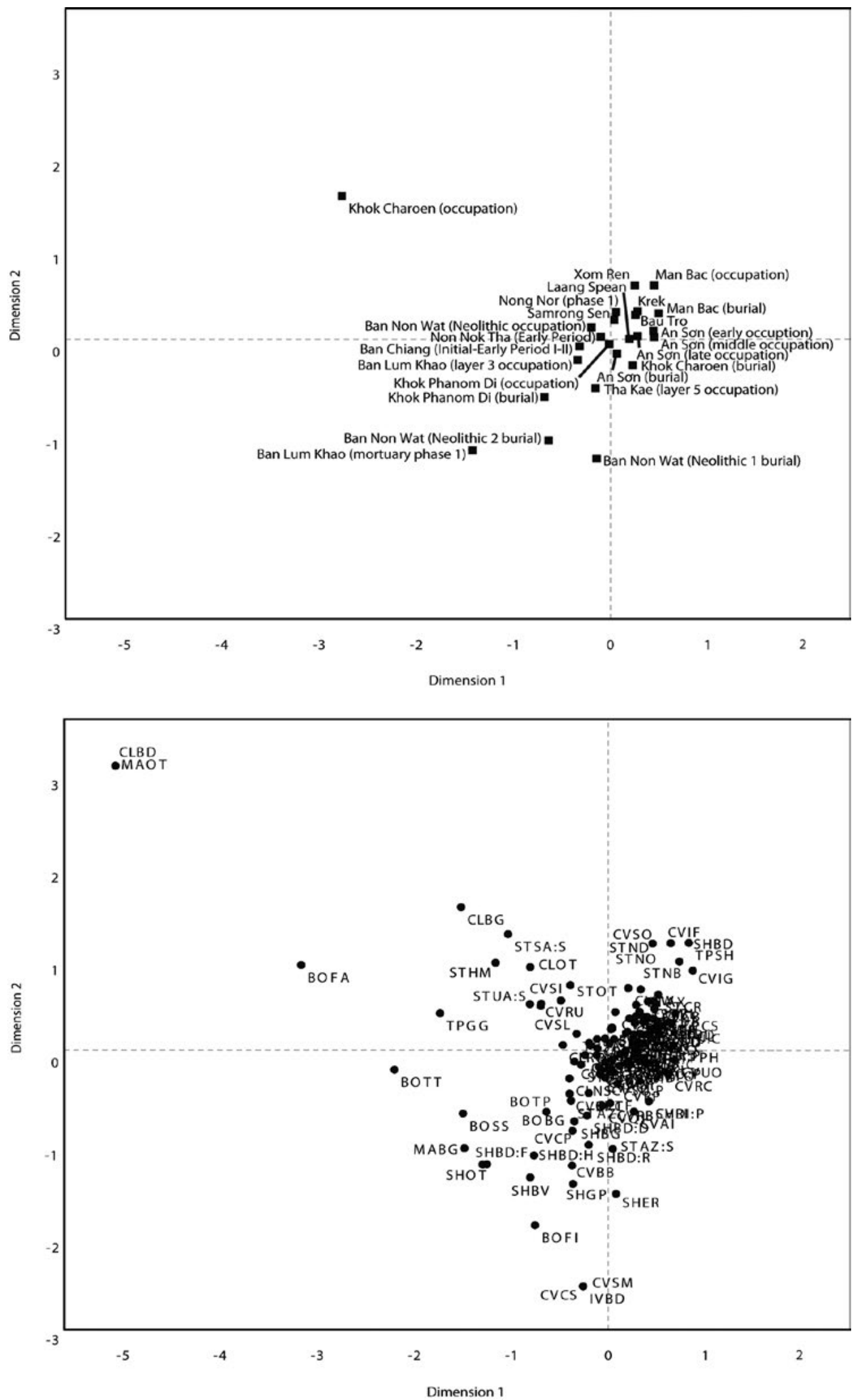

Figure 9.2 CA plots for the Southeast Asian Neolithic cultural variables. Occupation and burial data separated. Top: sites; bottom: variables. Refer to Table 9.2 for variable codes.

Source: c. Sarjeant. 


\section{Results}

Two CAs are presented here, one that separates the occupational and burial phases for each site when possible (Figure 9.2), and one that combines this data for each site except An Son (Figure 9.3). The variables are coded with an abbreviation, as summarised in Table 9.2. When the sites are separated into occupation and burial phases, the CA plot (Figure 9.2) shows a main cluster of sites that crosses the various regions of MSEA, unrelated to chronology. This main cluster includes Nong Nor, Samrong Sen, Krek, Bau Tro, Man Bac (burial), An Son (early, middle and late occupation), Laang Spean, Ban Non Wat (occupation), Non Nok Tha, Ban Chiang, Khok Phanom Di (occupation), An Son (burial), Khok Charoen (burial), and Ban Lum Khao (occupation); in summary, northern, central and southern Vietnam and Cambodia, together with the occupation phases from the northeast and southern coastal Thailand sites.

The An Son burials cluster more closely with the late occupation than the early or middle occupation, which is concordant with the dates for the burials. The occupation assemblages from Ban Non Wat and Khok Phanom Di may also have predominantly predated their burials, which may explain why these occupation phases do not cluster with these sites' burial phases but instead cluster with the An Son occupation phases. Finally, the majority of the variables are associated with this main cluster of sites.

Lying slightly outside of the main cluster, Man Bac (occupation) and Xom Ren are closely related to each other. This is because they share the presence of nephrite artefacts, shell temper in the ceramics, and geometric impressions, scroll incisions and eye-shaped incisions (pottery decorations). Outliers of the CA plot included Khok Charoen (occupation), because of the presence of clay beads and marble items; Ban Lum Khao (burial), because of its absence of artefact variability; Ban Non Wat Neolithic burial Phases 1 and 2, because of the presence of a range of shell, ivory and marble ornaments and curvilinear incisions and painting on the ceramic vessels; Tha Kae, because of the presence of painted curvilinear designs; and Khok Phanom Di (burial), because of the presence of a wide range of shell items.

Table 9.2 Analysed variables and codes.

\begin{tabular}{|l|l|}
\hline Code & Variables \\
\hline BOAW & bone awl \\
\hline BOBG & bone bangle \\
\hline BOBO & cattle remains \\
\hline BOCA & dog remains \\
\hline BOFA & other faunal remains \\
\hline BOFH & bone fishhook \\
\hline BOFI & fish remains \\
\hline BOOT & bone worked \\
\hline BOPT & bone tool/weapon point \\
\hline BOSS & pig remains \\
\hline BOTP & tooth pendant \\
\hline BOTT & turtle/tortoise remains \\
\hline CLAV & clay anvil \\
\hline CLBD & clay bead \\
\hline CLBG & clay bangle \\
\hline CLCO & clay counter/roundel \\
\hline CLNS & clay net sinker/weight \\
\hline CLOT & clay artefact \\
\hline
\end{tabular}




\begin{tabular}{|c|c|}
\hline Code & Variables \\
\hline CLPL & clay pellet \\
\hline CLRO & clay roller \\
\hline CLSW & clay spindle whorl \\
\hline CVAI & applique and incision on top \\
\hline CVAP & applique \\
\hline CVBB & black burnish/surface \\
\hline CVBO & decoration on body \\
\hline CVBS & decoration on base \\
\hline CVCB & combed \\
\hline CVCC & coarse cord-marking \\
\hline $\mathrm{CVCl}$ & curvilinear incision with impressed fill \\
\hline CVCM & cord-marking \\
\hline CVCO & ceramic vessel concave rim independent restricted \\
\hline CVCO:P & ceramic vessel concave rim independent restricted:pedestal \\
\hline CVCP & curvilinear painting \\
\hline CVCS & curvilinear incision with paint/slip/burnish fill \\
\hline CVDI & ceramic vessel direct independent restricted \\
\hline CVDI:P & ceramic vessel direct independent restricted:pedestal \\
\hline CVDS & dentate stamping \\
\hline CVEI & ceramic vessel everted independent restricted \\
\hline CVEI:C & ceramic vessel everted independent restricted:carinated \\
\hline CVEl:P & ceramic vessel everted independent restricted:pedestal \\
\hline CVFI & fingernail impression \\
\hline $\mathrm{CVHI}$ & horizontal incision \\
\hline CVIC & incised \\
\hline CVIF & geometric eye-shape incision with impressed or incised fill \\
\hline CVIG & geometric impressed \\
\hline CVII & incised and impressed \\
\hline CVIP & impressed \\
\hline CVLP & decoration at lip \\
\hline CVNI:C & ceramic vessel inverted independent restricted:carinated \\
\hline CVPC & punctate stamping: circular \\
\hline CVPD & decoration on pedestal \\
\hline CVPH & punctate stamping: hollow circular/large circular \\
\hline CVPI & paddle impression \\
\hline CVPQ & punctate stamping: quadrangular/triangular \\
\hline CVQI & geometric quadrangular incision with impressed fill \\
\hline CVQO & geometric quadrangular incision \\
\hline CVRB & red burnish \\
\hline CVRC & roulette stamping: zigzag line continuous \\
\hline CVRD & roulette stamping: dotted linear \\
\hline CVRM & decoration on rim \\
\hline CVRP & red paint \\
\hline CVRS & roulette stamping: square \\
\hline CVRT & roulette stamping: dotted zigzag line continuous \\
\hline CVRU & roulette stamping: unspecified \\
\hline
\end{tabular}




\begin{tabular}{|c|c|}
\hline Code & Variables \\
\hline CVRZ & roulette stamping: zigzag lines \\
\hline CVSD & decoration on pronounced shoulder \\
\hline CVSH & decoration on shoulder \\
\hline CVSI & $\mathrm{S}^{\prime}$ /scroll shape incision with impressed fill \\
\hline CVSL & red slip \\
\hline CVSM & shell impressed \\
\hline CVSO & $\mathrm{S}^{\prime}$ /scroll shape incision \\
\hline CVSR & ceramic vessel simple restricted \\
\hline CVSR:C & ceramic vessel simple restricted:carinated \\
\hline CVSR:P & ceramic vessel simple restricted:pedestal \\
\hline CVSU & ceramic vessel simple unrestricted \\
\hline CVSU:C & ceramic vessel simple unrestricted:carinated \\
\hline CVSU:P & ceramic vessel simple unrestricted:pedestal \\
\hline CVTF & geometric triangular/diamond incision with diagonal incision fill \\
\hline CVTI & geometric triangular/diamond incision with impressed fill \\
\hline CVTO & geometric/diamond triangular incision \\
\hline CVUI & geometric circular/semi-circular incision with impressed fill \\
\hline CVUO & geometric circular/semi-circular incision \\
\hline CVVI & vertical incision \\
\hline CVWL & white lime \\
\hline CVWV & wavy incision \\
\hline CVXI & criss-cross incision \\
\hline CVZZ & zigzag incision \\
\hline IVBD & ivory bead \\
\hline IVBG & ivory bangle \\
\hline MABG & marble bangle \\
\hline MAOT & marble other \\
\hline SHBD & shell bead \\
\hline SHBD:D & shell bead:disc shape \\
\hline SHBD:F & shell bead:funnel shape \\
\hline SHBD:H & shell bead:H-shape \\
\hline SHBD:R & shell bead:rectangular/barrel/cylindrical-shape \\
\hline SHBG & shell bangle \\
\hline SHBV & shell bivalve \\
\hline SHER & shell earring \\
\hline SHGP & shell gastropod \\
\hline SHOT & shell worked \\
\hline SHRI & shell ring \\
\hline STAX & stone axe \\
\hline STAZ & stone adze \\
\hline STAZ:S & stone adze:small \\
\hline STBD & stone bead \\
\hline STBG & stone bangle \\
\hline STBL & stone blade \\
\hline STBS & stone burnishing \\
\hline STCH & stone chisel \\
\hline
\end{tabular}




\begin{tabular}{|c|c|}
\hline Code & Variables \\
\hline STCR & stone core \\
\hline STFL & stone flake \\
\hline STHM & stone hammerstone \\
\hline STNB & stone nephrite bangle \\
\hline STND & stone nephrite bead \\
\hline STNO & stone nephrite other \\
\hline STOT & stone other \\
\hline STRO & stone red ochre \\
\hline STSA & stone shouldered adze \\
\hline STSA:S & stone shouldered adze:small \\
\hline STSS & stone polishing/sandstone/coarse grained \\
\hline STUA & stone unshouldered adze \\
\hline STUA:S & stone unshouldered adze:small \\
\hline STWH & stone whetstone/grinding stone/fine grained \\
\hline TPCL & other calcareous temper \\
\hline TPCS & coarse sand temper \\
\hline TPFB & fibre/rice chaff temper \\
\hline TPGG & grog temper \\
\hline TPPH & phosphate temper \\
\hline TPSA & sand temper \\
\hline TPSH & shell temper \\
\hline
\end{tabular}

Source: C. Sarjeant.

Further commentary for Figure 9.2 is provided as the second CA plot reveals clearer relationships between the sites. This is achieved by combining the occupation and burial phases so as to increase the number of variables that can be recorded as present for each site (Figure 9.3). It emphasises the differences between sites that clustered together in Figure 9.2 despite known marked differences in material culture between the sites. Seven apparent groups can be identified in the second CA plot (Figure 9.3), and the corresponding variables shared by the sites within each group are summarised in Table 9.3. Some of these groups correspond closely with those in Figure 9.2, such as group 6 (Xom Ren and Man Bac), while others correspond loosely, such as Group 7 (Laang Spean, Samrong Sen and Krek). Ban Lum Khao and An Son (burial) are the main outliers, although An Son (burial) also corresponds with Group 1, particularly the late occupation phase at An Son.

While ceramic vessel forms are highly variable and difficult to compare in such an analysis and ceramic temper sequences for most sites in the region are incompletely documented, Rispoli's (as previously analysed by Rispoli 1997, 2007) disentangling of the incised and impressed designs that predominate in the decorative modes of the assemblages has added to our understanding of the movements of these designs during the Neolithic. This extends to the relationship between these motifs and other material cultural variables within Southeast Asia. The distributions of selected analysed variables in the CAs, intended to be open-ended areas rather than to have rigid boundaries, are presented in Figures 9.4, 9.5 and 9.6. The absence of central Vietnamese sites in this comparative study is a notable deficiency, and hinders interpretation for MSEA as a whole. Further research across MSEA is needed to add to the currently available perspective. 
Table 9.3 The CA plots and contributing variables for groups in Figures 9.2 and 9.3.

\begin{tabular}{|c|c|c|}
\hline Group number & Corresponding sites & Corresponding variables \\
\hline 1 & $\begin{array}{l}\text { Bau Tro } \\
\text { An Son (early occupation) } \\
\text { Nong Nor (Phase 1) } \\
\text { An Son (middle occupation) } \\
\text { An Son (late occupation) } \\
\end{array}$ & $\begin{array}{l}\text { Shell rectangular beads } \\
\text { Circular and semi-circular incisions on ceramic vessels } \\
\text { Shouldered and unshouldered adzes, varying sizes } \\
\text { Concave rim ceramic vessels }\end{array}$ \\
\hline 2 & An Son (burial) & Concave rim ceramic vessels with pedestal \\
\hline 3 & $\begin{array}{l}\text { Ban Lum Khao } \\
\text { (Neolithic Layer } 3 \text { and Mortuary Phase 1) }\end{array}$ & Absence of artefact variability \\
\hline 4 & $\begin{array}{l}\text { Ban Non Wat } \\
\text { (Neolithic Phases } 1 \text { and 2) } \\
\text { Khok Charoen }\end{array}$ & $\begin{array}{l}\text { Shell artefacts } \\
\text { Marble artefacts } \\
\text { Ivory artefacts } \\
\text { Small adzes } \\
\text { Curvilinear incision and painting on ceramic vessels }\end{array}$ \\
\hline 5 & $\begin{array}{l}\text { Ban Chiang } \\
\text { (Initial-Early Period I-II) } \\
\text { Tha Kae (Layer } 5 \text { neolithic) } \\
\text { Non Nok Tha (Early Period) } \\
\text { Khok Phanom Di }\end{array}$ & $\begin{array}{l}\text { Shell artefacts } \\
\text { Ivory artefacts } \\
\text { Unshouldered adzes } \\
\text { Zigzag incision on ceramic vessels } \\
\text { Black surface treatment on ceramic vessels } \\
\text { Curvilinear incision and painting on ceramic vessels } \\
\text { S-shaped incision with impressed fill on ceramic vessels }\end{array}$ \\
\hline 6 & $\begin{array}{l}\text { Xom Ren } \\
\text { Man Bac }\end{array}$ & $\begin{array}{l}\text { Nephrite artefacts } \\
\text { Geometric impression on ceramic vessels } \\
\text { Shell temper in ceramic fabrics } \\
\text { Scroll incisions on ceramic vessels } \\
\text { Eye-shaped incisions on ceramic vessels }\end{array}$ \\
\hline 7 & $\begin{array}{l}\text { Laang Spean } \\
\text { Samrong Sen } \\
\text { Krek }\end{array}$ & $\begin{array}{l}\text { Flake and core stone tool artefacts } \\
\text { Hollow circle punctate stamping on ceramic vessels }\end{array}$ \\
\hline
\end{tabular}

Source: C. Sargeant.

\section{Comparison between An Son and MSEA material culture}

Many of the material culture variables studied in the CA are influenced by chronology. This may explain why An Son displays its greatest correspondence with two other early Neolithic sites, Nong Nor (Phase 1) and Bau Tro, in the CA (Figure 9.3). The particularly strong affinities between An Son and Nong Nor (Phase 1) include the band designs on the shoulders of ceramic vessels. One difference is the rarity of shell artefacts at An Son and their greater variety and abundance at Nong Nor (Phase 1), but this may be due to, respectively, restricted and ready access to a marine environment with suitable shells. 

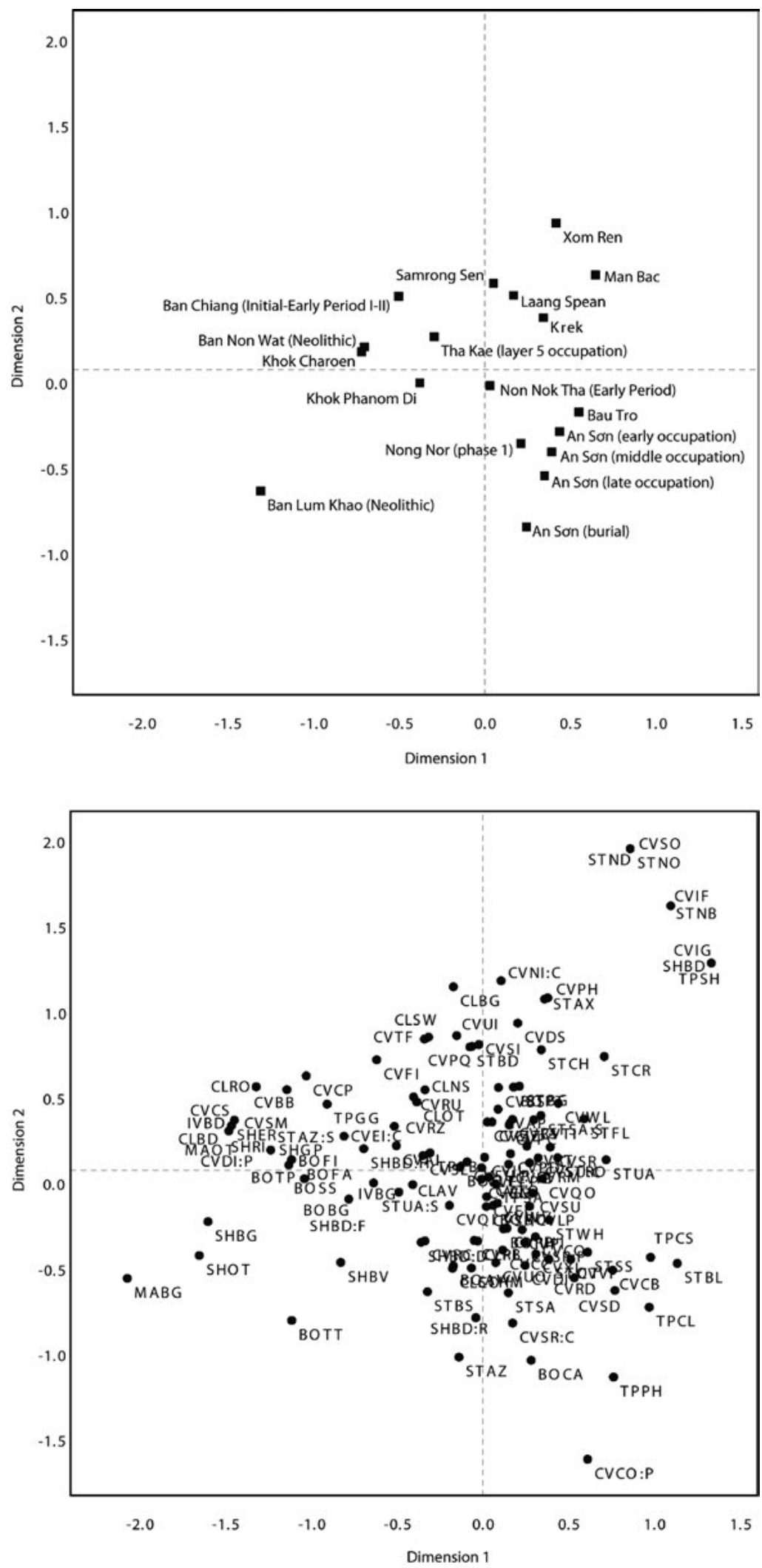

Figure 9.3 CA plots for the Southeast Asian Neolithic cultural variables. Occupation and burial data combined, except for An Son. Top: sites; bottom: variables. Refer to Table 9.2 for variable codes. Source: C. Sarjeant. 


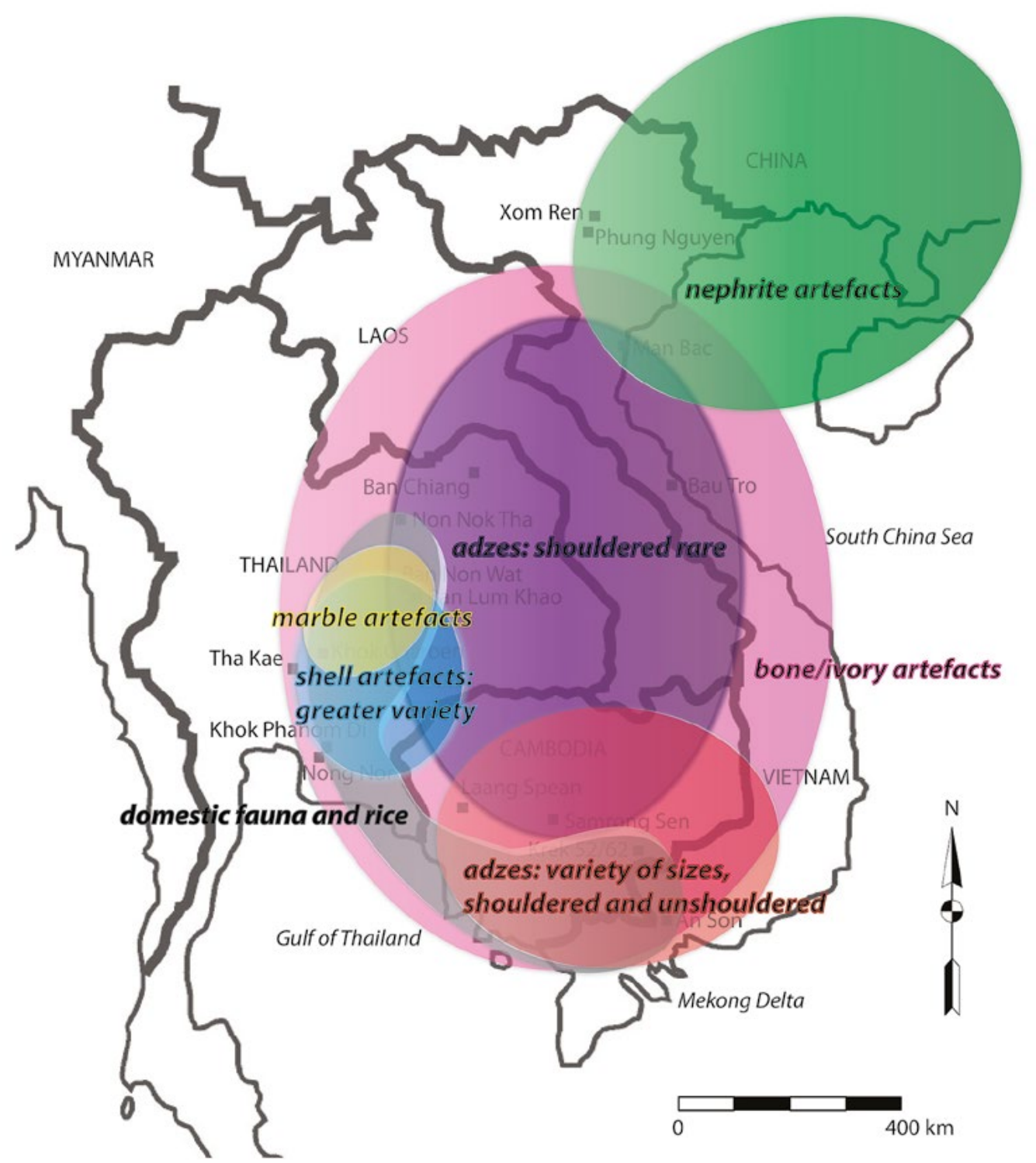

Figure 9.4 Distribution of notable non-ceramic material culture in Mainland Southeast Asia.

Source: C. Sarjeant.

However, not all early MSEA Neolithic sites are similar to An Son in their material culture. Khok Phanom Di is a case in point on account of its more variable and abundant bone and shell artefacts compared with An Son, and its presence of marble artefacts (absent from An Son). However, Khok Phanom Di would have had ready access to marine shell, potentially explaining this difference from An Son. An Son was also the more distant site from limestone and marble deposits, which in MSEA are located in the Lopburi region, and near Man Bac, Bau Tro, Samrong Sen and Laang Spean (Fromaget et al. 1971; Vimuktanandana 1999). Overland exchange of Lopburi marble a short distance south to Khok Phanom Di and a longer distance north to the Khorat Plateau is the likely explanation for the presence of marble artefacts at Khok Phanom Di and the Khorat Plateau sites. 


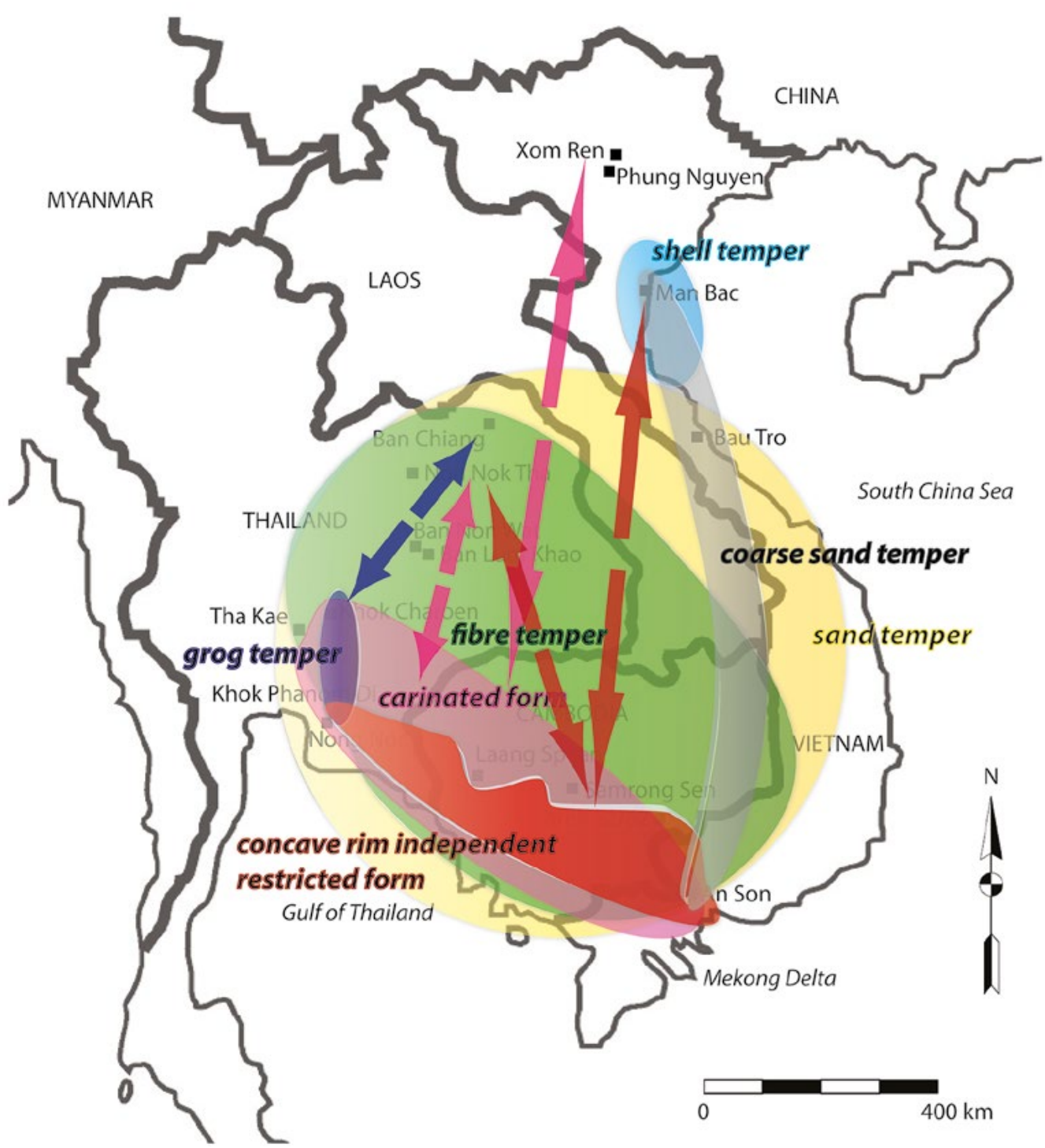

Figure 9.5 Distribution of notable An Son ceramic vessel forms and dominant tempers in Mainland Southeast Asia. The arrows point to sites beyond the coloured sphere with the specified variable.

Source: C. Sarjeant.

Suitable stone sources for adze production include basalt outcrops in Dong Nai Province, southeastern Cambodia and the Khorat Plateau in northeast Thailand, and granite outcrops near Khok Phanom Di and Nong Nor (Fromaget et al. 1971; Vimuktanandana 1999). The Dong Nai basalt was the closest significant source to An Son. The shape of the An Son adzes was probably related to the rectangular-sectioned adze technology based in the Dong Nai region, with the tools reduced and reworked at An Son to result in their notable variation in size. The southern Vietnam adze technology was unrelated to the technology of small, ovoid-sectioned basalt adzes in northeast Thailand. 


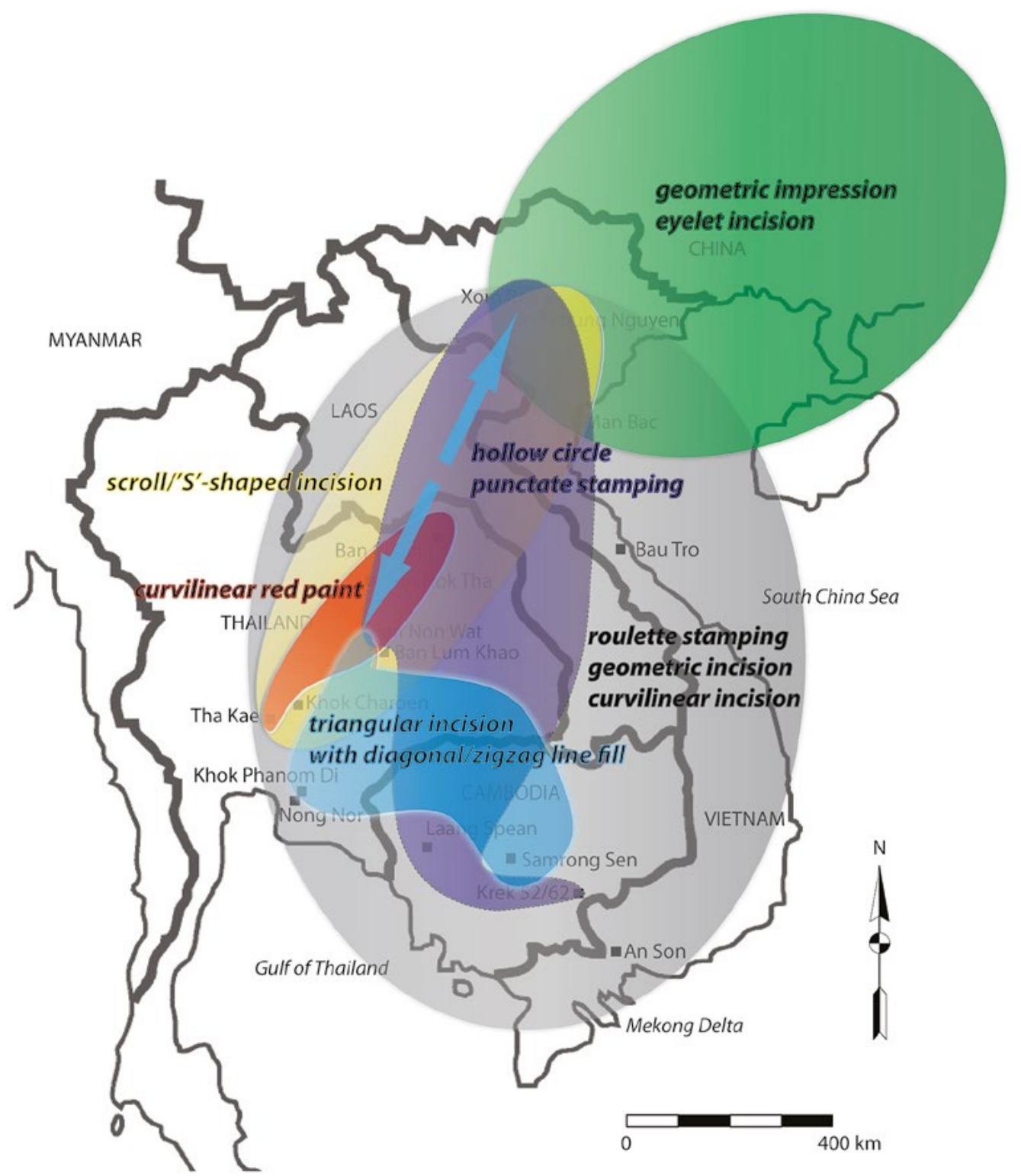

Figure 9.6 Distribution of notable modes of decoration on ceramic vessels in Mainland Southeast Asia. The arrows point to sites beyond the coloured sphere with the specified variable.

Source: C. Sarjeant.

Strong parallels have been established between the ceramic vessel forms of An Son and those at other Neolithic sites in southern Vietnam (Sarjeant 2012, 2014), but such parallels were limited in this study. Of the archaeological assemblages available for this study, the dominant restricted vessel form with a concave rim at An Son was restricted to the southern sites (including Khok Phanom Di and Krek), apart from some variations of this form observed at Man Bac. The concave rim forms were associated with band designs on the shoulder, typically roulette stamping between two horizontal incised lines. Roulette stamping, also known as rocker stamping, was formed by rolling a stamp with an impressed or relief motif around a vessel. The stamps could have been created by carving a cylindrical item, perhaps wood, or adhering plant weaving or knotted cord around a cylindrical item. While roulette stamping was highly sophisticated, detailed and varied at An Son, it was in fact a widespread mode of decoration in MSEA. 
Roulette stamping appeared alongside many other modes of incised and impressed motifs during the Neolithic at other MSEA sites (see Rispoli 1997) where, also unlike at An Son, many decorated vessels had incised and impressed motifs that extended onto the body below the shoulder. In addition, painted motifs and ' $S$ '-shaped incised motifs were restricted to northern Vietnam and northeast and central Thailand, and were never manifested in southern Vietnam. The limited variation in decorative mode at An Son, with a focus on variation within a single mode of decoration (roulette stamping) on one frequently produced vessel form, reflects an intensity in the ceramic manufacture of concave rim form vessels. While An Son was part of the incised and impressed tradition of Neolithic Southeast Asia, it was evidently not exposed to numerous decorative elaborations that held sway further north.

While the occurrence of roulette stamping is not unique to MSEA, and does not necessarily stipulate contact between sites from its presence alone, the overall combination of Neolithic features at An Son (domestic rice, dog and pig, polished stone technology, and incised and impressed ceramic vessels) implies an associated transference of this mode of decoration with Neolithic settlement. At the point of transference to southern Vietnam, certain material cultural variables were adopted and others were omitted. Those variables that were initially adopted developed locally over time, but contacts did not extend into the wider Neolithic world inclusive of ornate shell and marble ornaments, painted ceramics and increasingly variable incised ceramics. An Son was one of the sites at the 'end of the line' in terms of MSEA Neolithic traditions. It contrasts with centrally located sites like Ban Non Wat which received goods and technological ideas from both the south and north, visible in its shell and marble artefacts and its ceramics.

The likely immediate source for the An Son Neolithic was northeast and central Thailand, particularly in view of the specific parallels between An Son and Nong Nor (Phase 1) in the CA. There are also clear similarities between An Son and Krek in their material culture. While these are less clearly reflected in the CA, this could at least partly reflect taphonomic factors, because the local soil conditions at Krek did not allow for the preservation of bone and shell artefacts. In summary, there is evidence for long-lasting and widespread Neolithic traditions that extended to southern Vietnam, but little sign of direct contact between An Son and sites further north during the 1,000 years of occupation at An Son, when contact via material culture was limited to the more immediate vicinity of southern Vietnam and southeastern Cambodia.

\section{Towards a characterisation of Neolithic An Son}

Whilst there is general acceptance for a Neolithic transference from southern China to MSEA, with a potentially ultimate origin in the Yangtze River, its timing, events and routes via river courses or coastal lowlands continue to be discussed (Higham 2002; Rispoli 2007; Fuller et al. 2010; Nakamura 2010; Zhang and Hung 2010; Zhao 2010; Bellwood 2011; Castillo 2011; Higham et al. 2011; Lu 2011). Increasingly, more interpretations posit multiple movements over a period of time and the adoption of selected traits in the transition to agriculture (Zhang and Hung 2010). Rispoli (2007) proposes that particular traits were chosen or rejected as material culture was moved from the Yangtze into southern and southeastern China, and then into MSEA. Fuller (2011) hypothesises that distinct movements with taro and rice millet cultigens occurred at different times and may have overlaid former routes.

The ceramic evidence is consistent with hypotheses that propose riverine (as opposed to coastal) origins for Austroasiatic speakers, and specifically their movement down the Mekong (Sidwell and Blench 2011). This could be responsible for the appearance of a similar Neolithic expression, inclusive of incised and impressed decoration on the ceramics, alongside rivers in MSEA (Higham 2004; Bellwood 2005: 131-134; Rispoli 2007). While there is archaeobotanical evidence for the 
dispersal of rice cultivation along coastal lowlands and coastlines in Southeast Asia (Fuller et al. 2010; Fuller et al. 2011), there is currently a lack of ceramic evidence to support this. On the other hand, particularly if multiple waves of cultigens entered Southeast Asia (Fuller 2011), there may be no reason to expect a direct correspondence between rice and ceramic origins.

At An Son, the introductions of rice, domestic animals, polished stone tools and ceramics occurred together at or shortly after the initiation of the settlement. Thus, by the time cultivation and domestic animals reached southern Vietnam, there is evidence of a collective package associated with Neolithic occupation. This rapid adoption of a developed Neolithic culture was probably well-established in MSEA (Zhang and Hung 2010). However, the onset of this widespread Neolithic culture in southern Vietnam led to regionalisation and innovation at a local level almost immediately after settlement. Long-lasting traditions of ceramic manufacture, observed all over MSEA, were maintained as new ones were established at a local and regional level. The potters at An Son actively maintained ceramic traditions that connected southern Vietnam with the wider MSEA Neolithic, whilst also investing in new traditions that exhibited a local material identity.

The research into Neolithic MSEA presented here illustrates both consistency and discontinuity in terms of interaction with the Neolithic landscape:

1. An Son belongs to a cultural lineage connected to the sites of coastal central Thailand and Cambodia.

2. A more distant, perhaps ancestral, relationship is evident between southern Vietnam and northeast Thailand; however, a number of northeast Thailand traits did not reach southern Vietnam.

3. There is no clear relationship between the sites of southern Vietnam and northern Vietnam, which display distinct ceramic affinities.

4. More generally, there is evidence for separate northern and southern Neolithic traditions, whose components intermingled only in the area of northeast and inland central Thailand and northern Cambodia.

Distinct affinities are exhibited by the sites of northern and southern Vietnam and, while the northern Vietnam ceramic practices are evident in central and northeast Thailand, it appears that some of these never reached southern Vietnam. Thus, regardless of the actual date and route for the initial Neolithic occupation of southern Vietnam, its sites evidently belonged to a major tradition that appears to have followed the Mekong River and its major tributaries. This is suggestive of interactions and movements of Neolithic peoples from Cambodia and northeast Thailand into southern Vietnam, and also across land and/or coastlines from central Thailand, through Cambodia, to southern Vietnam.

\section{Acknowledgements}

I would firstly like to thank my $\mathrm{PhD}$ supervisor, Professor Peter Bellwood, and his continuing support of my research on the Neolithic occupation of Southeast Asia. I would also like to thank Philip J. Piper and Hsiao-chun Hung for inviting me to contribute to Peter's Festschrift. I thank Dougald O'Reilly at The Australian National University for his supervision. I also would like to thank Marc Oxenham at ANU, Bui Chi Hoang of the Centre for Archaeological Studies, Southern Institute of Social Sciences, Ho Chi Minh City, and Nguyen Kim Dung of the Institute of Archaeology, Hanoi. The excavations at An Son were funded by a Discovery Grant from the Australian Research Council (DP0666607). My own research was funded by an Australian Postgraduate Award. There are a number of individuals who assisted during the An Son ceramic sorting process at the Long An Provincial Museum: Nguyen Khanh Trung Kien, Nguyen Manh 
Quoc, Dang Ngoc Kinh, Nguyen Khai Quynh, Le Hoang Phong, Nguyen Phuong Thao, Tran Thi Kim Quy, Vo Thanh Huong, and Van Ngoc Bich. I would like to sincerely thank Nguyen Khanh Trung Kien for his help in accessing museums in southern Vietnam. The comparative sites were supported by information provided by Peter Bellwood, Charles Higham, Nigel Chang, Fiorella Rispoli and Roberto Ciarla, Helmut Loofs-Wissowa, Hubert Forestier and Heng Sophady, Nguyen Kim Dung and Nishimura Masanari.

\section{References}

Albrecht, G., M. Noel Haidle, C. Sivleng, L.H. Heang, S. Heng, T. Heng, S. Mao, K. Sirik, S. Som, C. Thuy and L. Vin. 2000. Circular earthwork Krek 52/62: Recent research on the prehistory of Cambodia. Asian Perspectives 39(1-2): 20-46. doi.org/10.1353/asi.2000.0002.

Baxter, M. 2003. Statistics in Archaeology. London: Arnold.

Bayard, D.T. 1977. Phu Wiang pottery and the prehistory of Northeastern Thailand. Modern Quaternary Research in Southeast Asia 3: 57-102.

Bayard, D.T. and W.G. Solheim, II. 2009. Archaeological Excavations at Non Nok Tha, Thailand. guampedia.com/archaeological-excavations-at-non-nok-tha-thailand, viewed 23 November 2011.

Bellwood, P. 2005. First Farmers: The Origins of Agricultural Societies. Malden, MA: Blackwell.

- 2011. The checkered prehistory of rice movement southwards as a domesticated cereal-from the Yangzi to the Equator. Rice 4(3): 93-103.

Bellwood, P. and M. Oxenham. 2008. The expansions of farming societies and the role of the Neolithic Demographic Transition. In B-A. Jean-Pierre and B.-Y. Ofer (eds), The Neolithic Demographic Transition and its Consequences, pp. 13-34. Netherlands: Springer Netherlands. doi.org/10.1007/9781-4020-8539-0_2.

Bellwood, P., M. Oxenham, C.H. Bui, K.D. Nguyen, A. Willis, C. Sarjeant, P. Piper, H. Matsumura, K. Tanaka, T. Higham, M.Q. Nguyen, N.K. Dang, K.T.K. Nguyen, T.H. Vo, N.B. Van, T.K.Q. Tran, P.T. Nguyen, F. Campos, Y. Sato, L.C. Nguyen and N. Amano. 2011. An Son and the Neolithic of Southern Vietnam. Asian Perspectives 50: 144-174. doi.org/10.1353/asi.2011.0007.

Bubpha, S. 2003. A comparative study of ceramic petrography from Ban Don Thong Chai and Ban Chiang. Bulletin of the Indo-Pacific Prehistory Association 23(1): 15-18.

Bulbeck, D. 2011. Biological and cultural evolution in the population and culture history of Homo sapiens in Malaya. In N. Enfield (ed.), Dynamics of Human Diversity: The Case of Mainland Southeast Asia, pp. 207-255. Canberra: Pacific Linguistics.

Caramani, D. 2009. Introduction to the Comparative Method with Boolean Algebra. Los Angeles: Sage. doi.org/10.4135/9781412984690.

Carbonnel, J.P. and G. Delebrias. 1968. Premiere datations absolues de trois gisements neolithiques cambodgiens (First absolute dates of three Neolithic Cambodian deposits). Comptes Rendus de l'Academie des Sciences 267: 1432-1434 (in French).

Castillo, C. 2011. Rice in Thailand: The archaeobotanical contribution. Rice 4(3): 114-120. doi. org/10.1007/s12284-011-9070-2.

Chang, N. 2004. The personal ornaments. In C.F.W. Higham and R. Thosarat (eds), The Excavation of Ban Lum Khao, pp. 217-230. Bangkok: The Thai Fine Arts Department. 
Ciarla, R. 1992. The Thai-Italian Lopburi regional archaeological project: preliminary results. In G. Ian, (ed.), Southeast Asian Archaeology 1990: Proceedings of the 3rd Conference of the European Association of Southeast Asian Archaeologists, pp. 111-128. Hull: Center for South-East Asian Studies, University of Hull.

. n.d. The Thai-Italian 'Lopburi Regional Archaeological Project' - LoRAP: A preliminary report of fifteen years of activities. Unpublished report. Italian Institute for Africa and the Orient, Rome.

Dega, M.F. 1999. Circular settlements within eastern Cambodia. Indo-Pacific Prehistory Association Bulletin 18: 181-190. doi.org/10.7152/bippa.v18i0.11713.

. 2002. Prehistoric Circular Earthworks of Cambodia. Oxford: Archaeopress (British Archaeological Reports).

Dunnell, R.C. 1986. Methodological issues in Americanist artifact classification. In S. Michael (ed.), Advances in Archaeological Method and Theory, pp. 149-207. New York: Academic Press. doi. org/10.1016/B978-0-12-003109-2.50007-6.

Fromaget, J., E. Saurin and H. Fontaine. 1971. Geological Map of Vietnam, Cambodia and Laos. 3rd edition. Dalat: National Geographic Directorate of Vietnam.

Fuller, D.Q. 2011. Pathways to Asian civilizations: Tracing the origins and spread of rice and rice cultures. Rice 4(3): 78-92. doi.org/10.1007/s12284-011-9078-7.

Fuller, D.Q., Y. Sato, C. Cristina, L. Qin, A. Weisskopf, E. Kingwell-Banham, J. Song, S.M. Ahn and J. van Etten. 2010. Consilience of genetics and archaeobotany in the entangled history of rice. Archaeological and Anthropological Sciences 2(2): 115-131. doi.org/10.1007/s12520-010-0035-y.

Fuller, D.Q., J. van Etten, K. Manning, C. Castillo, E. Kingwell-Banham, A. Weisskopf, L. Qin, Y. Sato and R.J. Hijmans. 2011. The contribution of rice agriculture and livestock pastoralism to prehistoric methane levels: An archaeological assessment. The Holocene 21(5): 743-759. doi. org/10.1177/0959683611398052.

Gorman, C.F. and P. Charoenwongsa. 1976. Ban Chiang: A mosaic of impressions from the first two years. Expedition 18(4): 14-26.

Hán, V.K. 2009. Xom Ren: Mot di tich khao co dac biet quan trong cua thoi dai do dong Viet Nam (Xom Ren: The Archaeological Importance of Bronze Age Vietnam). Hanoi: Nha Xuat Ban Dai Hoc Quoc Gia Ha Noi (in Vietnamese).

Heng, S. 2007. A Study of Polished Stone Tools from Samrong Sen, Cambodia: the French Museum Collections. Unpublished Master of Arts thesis. Departement de Prehistoire, Museum National d'Histoire Naturelle, Paris.

Higham, C.F.W. 1996. The Bronze Age of Southeast Asia. Cambridge: Cambridge University Press.

2002. Languages and farming dispersal: Austroasiatic languages and rice cultivation. In P.

Bellwood and C. Renfrew (eds), Examining the Farming/Language Dispersal Hypothesis, pp. 223-232.

Cambridge: McDonald Institute for Archaeological Research.

- 2004. Mainland Southeast Asia from the Neolithic to the Iron age. In I. Glover and P.

Bellwood (eds), Southeast Asia: From Prehistory to History, pp. 41-67. London and New York:

RoutledgeCurzon.

2009a. Layer five. In C.F.W. Higham and A. Kijngam (eds), The Excavation of Ban Non Wat.

Part One: Introduction, pp. 27-31. Bangkok: The Thai Fine Arts Department. 
- 2009b. Layer four. In C.F.W. Higham and A. Kijngam (eds), The Excavation of Ban Non Wat. Part One: Introduction, pp. 33-50. Bangkok: The Thai Fine Arts Department.

- 2009c. Summary. In C.F.W. Higham and A. Kijngam (eds), The Excavation of Ban Non Wat. Part One: Introduction, pp. 251-257. Bangkok: The Thai Fine Arts Department.

- 2011a. Introduction. In C.F.W. Higham and A. Kijngam (eds), The Excavation of Ban Non Wat. Part Two: The Neolithic Occupation, pp. 1-3. Bangkok: The Thai Fine Arts Department.

- 2011b. Summary and conclusions. In C.F.W. Higham and A. Kijngam (eds), The Excavation of Ban Non Wat. Part Two: The Neolithic Occupation, pp. 199-212. Bangkok: The Thai Fine Arts Department.

Higham, C.F.W. and R. Bannanurag. 1990. The Excavation of Khok Phanom Di, a Prehistoric Site in Central Thailand. Volume I: Excavation, Chronology and Human Burials. London: The Society of Antiquaries of London.

Higham, C.F.W. and T. Higham. 2009a. The chronology. In C.F.W. Higham, and A. Kijngam (eds), The Excavation of Ban Non Wat. Part One: Introduction, pp. 17-25. Bangkok: The Thai Fine Arts Department.

- 2009b. A new chronological framework for prehistoric Southeast Asia, based on a Bayesian model from Ban Non Wat. Antiquity 83: 125-144. doi.org/10.1017/S0003598X00098136.

Higham, C.F.W. and A. Kijngam (eds). 2009. The Excavation of Ban Non Wat: Introduction. Bangkok: The Thai Fine Arts Department.

- 2011. The Excavation of Ban Non Wat. Part Two: The Neolithic Occupation. Bangkok: The Thai Fine Arts Department.

Higham, C.F.W. and R. Thosarat (eds). 1998a. The Excavation of Nong Nor: A Prehistoric Site in Central Thailand. Dunedin: Department of Anthropology, University of Otago.

1998b. Section three: The first occupation phase. In C.F.W. Higham and R. Thosarat (eds), The Excavation of Nong Nor: A Prehistoric Site in Central Thailand, pp. 91-92. Dunedin: Department of Anthropology, University of Otago.

- 2004a. The burials from mortuary phase 1. In C.F.W. Higham, and R. Thosarat (eds), The Excavation of Ban Lum Khao, pp. 23-32. Bangkok: The Thai Fine Arts Department.

- 2004b. The Excavation of Ban Lum Khao. Bangkok: The Thai Fine Arts Department.

- 2004c. The Excavation of Khok Phanom Di, a Prehistoric Site in Central Thailand. Volume VII: Summary and Conclusions. London: The Society of Antiquaries.

Higham, C.F.W. and W. Wiriyaromp. 2011a. Neolithic phase one. In C.F.W. Higham and A. Kijngam (eds), The Excavation of Ban Non Wat. Part Two: The Neolithic Occupation, pp. 15-64. Bangkok: The Thai Fine Arts Department.

- 2011b. Neolithic phase two. In C.F.W. Higham and A. Kijngam (eds), The Excavation of Ban Non Wat. Part Two: The Neolithic Occupation, pp. 65-92. Bangkok: The Thai Fine Arts Department.

Higham, T.F.G. and A. Hogg. 1998. The radiocarbon chronology. In C.F.W. Higham and R. Thosarat (eds), The Excavation of Nong Nor: A Prehistoric Site in Central Thailand, pp. 23-25. Dunedin: Department of Anthropology, University of Otago.

Higham, C.F.W., X. Guangmao and L. Qiang. 2011. The prehistory of a Friction Zone: first farmers and hunters-gatherers in Southeast Asia Antiquity 85(328): 529-543. 
Ho, C.M.W. 1984. The Pottery of Kok Charoen and Its Farther Context. Unpublished PhD thesis, Instritute of Archaeology, University of London, London.

Lu, T.L-D. 2011. Early pottery in South China. Asian Perspectives 49(1): 1-42. doi.org/10.1353/ asi.2010.0003.

Malleret, L. 1963. L'Archeologie du delta du Mekong, tome quatrieme, Le Cisbassac (The Archaeology of the Mekong Delta, the fourth volume, The Cisbassac). Paris: École française d'Extrême-Orient (in French).

Matsumura, H. and M.F. Oxenham. 2011. Introduction: Man Bac biological research objectives. In M.F. Oxenham, H. Matsumura and K.D. Nguyen (eds), Man Bac: The Excavation of a Neolithic Site in Northern Vietnam: The Biology, pp. 1-8. Terra Australis 33. Canberra: ANU E Press.

McGovern, P.E., W.V. Watson, and C.W. Joyce. 1985. Ceramic technology at prehistoric Ban Chiang, Thailand: Physiochemical analyses. MASCA Journal 3(4): 104-113.

Mourer, C. and R. Mourer. 1970. The prehistoric industry of Laang Spean, Province Battambang, Cambodia. Archaeology and Physical Anthropology in Oceania 5: 128-146.

Mourer, R. 1977. Laang Spean and the prehistory of Cambodia. Modern Quaternary Research in Southeast Asia 3: 29-56.

Nakamura, S. 2010. The origin of rice cultivation in the Lower Yangtze Region, China. Archaeological and Anthropological Sciences 2(2): 107-113. doi.org/10.1007/s12520-010-0033-0.

Neff, H. 1993. Theory, sampling, and analytical techniques in the archaeological study of prehistoric ceramics. American Antiquity: 23-44. doi.org/10.1017/S0002731600056079.

Nguyen, K.D. 2006. Preliminary report on the Vietnamese-Japanese-Australian archaeological excavation at Man Bac site. Unpublished report. Anthropological and Archaeological Study on the Origin of Neolithic People in Mainland Southeast Asia, Hanoi.

Nishimura, M. 2002. Chronology of the Neolithic Age in the southern Vietnam. Journal of Southeast Asian Archaeology 22: 25-57.

Nishimura, M. and K.D. Nguyen. 2002. Excavation of An Son: A Neolithic mound site in the middle reach of the Vam Co Dong River, Southern Vietnam. Bulletin of the Indo-Pacific Prehistory Association 22: 101-109.

O’Reilly, D.J.W. 1998. The ceramic analysis. In C.F.W. Higham, and R. Thosarat (eds), The Excavation of Nong Nor: A Prehistoric Site in Central Thailand, pp. 97-118. Dunedin: Department of Anthropology, University of Otago.

Oxenham, M. and N. Tayles. 2006. Bioarchaeology of Southeast Asia. Cambridge: Cambridge University Press. doi.org/10.1017/CBO9780511584220.

Oxenham, M., H. Matsumura, K. Domett, K.T. Nguyen, K.D. Nguyen, L.C. Nguyen, D. Huffer and S. Muller. 2008. Health and the experience of childhood in late neolithic Viet Nam. Asian Perspectives 47(2): 190-209. doi.org/10.1353/asi.0.0001.

Oxenham, M., H. Matsumura, and K.D. Nguyen (eds). 2011. Man Bac: The Excavation of a Neolithic Site in Northern Vietnam: The Biology. Terra Australis 33. Canberra: ANU E Press.

Patte, E. 1924. Le Kjokkenmodding neolithique du Bau Tro a Tam-toa pres de ng-hi (Annam) (The Neolithic of Bau Tro). Bulletin de l'Ecole Francaise D'Extreme-Orient 24(1): 521-561 (in French). doi.org/10.3406/befeo.1924.3013. 
Pham, T.N. 1997. Bau Tro culture; characteristic features and regional variants. Journal of Southeast Asian Archaeology 17(6): 7-16.

Piper, P., F. Campos, N.K. Dang, N. Amano, M. Oxenham, C.H. Bui, P. Bellwood and A. Willis. 2014. Early evidence for pig and dog husbandry from the Neolithic site of An Son, southern Vietnam. International Journal of Osteoarchaeology 24: 68-72. doi.org/10.1002/oa.2226.

Rispoli, F. 1992. Preliminary report on the pottery from Tha Kae, Lopburi, central Thailand. In I. Glover (ed.), Southeast Asian Archaeology: Proceedings of the Third Conference of the European Association of Southeast Asian Archaeologists, pp. 129-142. Hull: Centre for South-East Asian Studies.

- 1997. Late third-mid second millennium BC pottery traditions in central Thailand: some preliminary observations in a wider perspective. In R. Ciarla and F. Rispoli (eds), Southeast Asian Archaeology 1992: Proceedings of the Fourth International Conference of the European Association of the South-East Asian Archaeologists, pp. 59-97. Rome: Instituto Italiano per l'Africa e L'Oriente.

- 2007. The incised \& impressed pottery style of mainland Southeast Asia: following the paths of Neolithisation. East and West, a quarterly published by the Istituto Italiano per l'Africa e l'Oriente 57(1-4): 235-304.

Sarjeant, C. 2012. The Role of Potters at Neolithic An Son, Southern Vietnam. Unpublished PhD thesis, School of Archaeology and Anthropology, The Australian National University, Canberra.

- 2014. Contextualising the Neolithic Occupation of Southern Vietnam: The Role of Ceramics and Potters at An Son. Terra Australis 42. Canberra: ANU Press.

Sidwell, P. and R. Blench. 2011. The Austroasiatic Urheimat: the southeastern riverine hypothesis. In N.J. Enfield (ed.), Dynamics of Human Diversity: the case of mainland Southeast Asia, pp. 315-343. Canberra: Pacific Linguistics.

Smith, M.E. and P. Peregrine. 2012. Approaches to comparative analysis in archaeology. In Michael E. Smith (ed.), The Comparative Archaeology of Complex Societies, pp. 4-20. Cambridge: Cambridge University Press.

Vanna, L. 2002. The Archaeology of Shell Matrix Sites in the Central Floodplain of the Tonle Sap River, Central Cambodia (The Shell Settlement Site of Samrong Sen and its Cultural Complexity). Unpublished PhD thesis, Sophia University, Tokyo.

Vimuktanandana, S. 1999. Geological Map of Thailand. Geological Survey Division, Bangkok: Department of Mineral Resources.

Vincent, B.A. 2004. The Excavation of Khok Phanom Di, a Prehistoric Site in Central Thailand. Volume VI: The Pottery, Other Ceramic Materials and their Cultural Role. The Material Culture (Part II). London: The Society of Antiquaries of London.

VSN International. 2011. GenStat for Windows. 14th Edition. VSN International, Hemel Hempstead, UK. www.GenStat.co.uk, viewed 8 April 2011.

Watson, W. 1979. Kok Charoen and the early Metal Age of central Thailand. In R.B. Smith and W. Watson (eds), Early South East Asia: Essays in Archaeology, History and Geographical Geography, pp. 53-62. New York and Kuala Lumpur: Oxford University Press.

Wiriyaromp, W. 2007. The Neolithic Period in Thailand. Unpublished PhD thesis, Department of Anthropology, University of Otago, Dunedin. 
- 2011. The wider relationships of the Neolithic 1 ceramics. In C.F.W. Higham and A. Kijngam (eds), The Excavation of Ban Non Wat. Part Two: The Neolithic Occupation, pp. 108-123. Bangkok: The Thai Fine Arts Department.

Zhang, C. and H.-c. Hung. 2010. The emergence of agriculture in southern China. Antiquity 84: 11-25. doi.org/10.1017/S0003598X00099737.

Zhao, Z. 2010. New data and new issues for the study of origin of rice agriculture in China. Archaeological and Anthropological Sciences 2(2): 99-105. doi.org/10.1007/s12520-010-0028-x. 
This text is taken from New Perspectives in Southeast Asian and Pacific Prehistory, edited by Philip J. Piper, Hirofumi Matsumura and David Bulbeck, published 2017 by ANU Press, The Australian National University, Canberra, Australia. 